DOI: $10.15503 /$ jecs20162.89.99

\title{
TEACHING AND RESEARCHING STAGE SPEECH (CONNECTING THEORY AND PRACTICE, SCIENCE AND ART)
}

\author{
NINA ŽAVBI MILOJEVIĆ \\ Academy of Theatre, Radio, Film and Television, \\ University of Ljubljana, \\ Nazorjeva 3, Ljubljana, Slovenia \\ E-mail address: nina.zavbi.milojevic@gmail.com
}

\begin{abstract}
The article deals with teaching and researching stage speech on the supposition that researching stage speech influences how we teach stage speech. Stage speech is an artistic speech that researchers try to study and explain in a scientific manner, i.e. with scientific terminology and methods. Modern studies of stage speech are interdisciplinary (they combine phonetics and theatre studies, literary theory and history, sociology, etc.) and no longer just studies on a stricly linguistic (phonetic) level. The article shows a model of a scientific and interdisciplinary study of stage speech and its influence on or connection to how it is taught. The teaching of stage speech, which is shown on the example of students of Stage Acting at the Academy of Theatre, Radio, Film and Television, balances between science and art as well as between theory and practice. The article demonstrates that researching stage speech influences the teaching that is also interdisciplinary, based on artistic and scientific concepts and constantly combines theory and practice.
\end{abstract}

Key words: stage speech, teaching, researching, theory and practice, science and art

\section{INTRODUCTION}

Stage speech is »speech based on clear articulation, appropriate audibility and voice expressiveness, consistent with the circumstances of the text and of the stage and theatre aesthetics « ${ }^{1}$ (Humar et. al., 2007, p. 135) and occurs on stage, as is evident from the name. The actor may be creative with his speech to a certain degree - mainly with the use of different prosodic elements, such as pause, intonation, register and timbre, loudness and tempo (Podbevšek, 2010, p. 199). Stage speech is as much a subject of teaching as it is a subject of

1 All quotes that are originally in the Slovene language were translated into English by Andreja Miklavčič. 
research for the researchers in the area of speech, who are at the same time also teaching speech at the Academy of Theatre, Radio, Film and Television in Ljubljana. Both researching and teaching are inseparably connected processes - the knowledge acquiered in research is transferred into the teaching practice and teaching also somewhat influences the subject of research as it influences the researcher, who is at the same time also the teacher. That is why this article tries to connect the two spheres - the teaching and researching the phenomenon of stage speech, its history and what it is today, with innovative and interdisciplinary approaches.

Throughout the long history of the Academy of Theatre, Radio, Film and Television, University of Ljubljana² (abbreviation: UL AGRFT) future actors have learnt in detail about the phenomenon of speech as one of their two basic means of expression - the other being movement. Especially in the s.c. dramatic or repertory theatre stage speech is one of the important elements of staging that communicate the director's vision in a concrete staging the other being lights, costumes, blocking, set, music, etc. (Žavbi Milojević, 2013a, p. 651). In this article I will briefly present the historical development of teaching stage speech at UL AGRFT, then I will discuss the concept of modern teaching of stage speech to students of Stage Acting. My main goal is to show how intertwined theoretical and practical contents are and how teachers and students are constantly involved in their professional environment through productions (theatre, radio, television, film).

However, there is another duality in the work of a teacher/researcher of stage speech that I wish to emphasise and that is the constant reduction of the gap between science and art or the research of an artistic phenomenon with a scientific apparatus. Namely, researching stage speech cannot be the same as researching nonartistic speech since stage speech is an artistic phenomenon with its own rules $^{3}$ (Podbevšek, 2013b, p. 9) that the researcher must understand and consider when he conducts his research. Stage speech never occurs naturally or spontaneously. It demands longterm preparations and it is a result of joint efforts of different experts and professional speakers, in our case usually actors. In this article I will present modern methods of researching stage speech ${ }^{4}$ and the connection with the modern methods of teaching stage speech. I will try to show that modern methods of research also influence the modern methods of teaching this artistic phenomenon.

2 It was founded in 1946 (70 years ago) as the Academy of Drama Arts.

3 By comparing artistic and school interpretations Katarina Podbevšek proved that all prosodic elements are used with greater precision and intensity in artistic interpretations. There are also more elements of nonverbal communication which are also more intense (Podbevšek, 2007, p. 245).

4 Modern methods of researching stage speech upgrade traditional phonetic studies (audio analysis) with use of objective analitical methods such as phonetic analysis with computer programme (Praat). 


\section{RESEARCHING STAGE SPEECH}

As researchers of stage speech we often deal with the dilemma of how we can scientifically understand and research stage speech since it is definitely an artistic phenomenon. How can we even begin to explain art in a scientific manner? Katarina Podbevšek was one of the first in Slovenia who scientifically researched and explained stage speech by using her own methodology. Nevertheless, she understood the difference between stage and nonartistic speech, how stage speech functions together with other elements of staging as a part of the director's concept (Podbevšek, 2012, p. 249). She also claims that in times of great changes in the world "the interest in researching stage speech increased" (Podbevšek, 2013, p. 10) - research was mainly influenced by technological development. Linguistics (phonetics), which used to be the only field of researching stage speech, opened its borders and created an interdisciplinary field where several different areas are involved in the analysis of speech (psychology, philosophy, theories of articulation, pragmatics, anthropology, language technology, etc.) (Podbevšek, 2013, p. 10). A researcher and professor at the Chair of Speech at UL AGRFT researches speech with audio analysis - by using audio-visual recordings whereby she focuses on "the manner in which a written text is transferred into spoken text" (Podbevšek, 2006a, p. 101) mostly by analysing prosodic and nonverbal (mimic, gesture, movement) elements of speech. I have adopted Podbevšek's process of analysis; however, I have added one more step - a phonetic analysis with the help of computer programmes. In this way the researcher's audioanalysis is checked and substantiated with measurable data.

I present a short overview of researching stage speech more objectively. I research stage speech in connected stages that are dependent on each other (Žavbi Milojević, 2013b, p. 217, 218). The first stage is determining the difference between the dramatic text and the playscript ${ }^{5}$, i.e. a production text. At this stage I focus on the written text and amongst other things I study dramaturgical changes of dramatic text which are explained by theatre studies. All the other stages of research deal with the spoken text, stage speech - speech delivered by actors on stage (mainly phonetic analysis) The first step of stage speech analysis is done by audio analysis and the second step is done by a phonetic computer program. I use the free computer programme Praat which is very appropriate for this kind of analysis because of its availability and simplicity. This final stage of analysis of stage speech is new in Slovenia, however, it has been used for a longer period of time by researchers studying other types of spoken texts, e.g. media speech (Tivadar) and researchers of stage speech in other parts of the world (Varošanec-Škarić, Vrban Zrinski).

The modern research of stage speech is shown on the example of a staging of I. Cankar's The Serfs, directed by Sebastijan Horvat in Slovene Permanent

5 Production text is »text delivered by performers in a staging and can sometimes differ from the dialogue written in the dramatic text« (Humar et. al., 2007, p. 193). 
Theatre in Trieste (Slovensko stalno gledališče v Trstu) in season 2014/2015 6 . I will only present a small segment of my audio analysis and Praat phonetic programme analysis. For the purpose of understanding the whole process I present the summary of all the stages of my research:

1. An analysis of the playscript in comparison with the dramatic text - has the dramatic text been changed in the sense of dramaturgical cuts (shortening the text), have parts of other texts (either dramatic or other texts) been added, has the register been changed so that the text is less formal or changed from standard to nonstandard language, has the dramatic text been changed in any other way.

2. Audio analysis of stage speech - analysing individual parts of the playscript in terms of nonverbal communication (mimic, gesture, movement on stage, etc.) as can be seen on the video of the staging, and in terms of prosodic elements of speech - pause, register, intonation, tempo, loudness. Pre-arranged symbols are used to mark the above mentioned prosodic elements in the transcription ${ }^{5}$ of the stage speech performed by actors on stage.

3. Analysis with Praat computer programme - short spoken segments are analysed with Praat and by doing so we check our audio analysis results and make sure that they are as objective as possible.

4. Interpretation of results - we interpret the results of the audio analysis and Praat analysis with an interdisciplinary approach (combining phonetics, theatre studies, sociology, etc.). We measure the intensity of the prosodic elements used, however, we cannot measure the effect achieved by the actors or how stage speech functions within the staging as a whole. Phonetic analysis is interpreted within dramaturgical concepts, because stage speech is a phenomenon that cannot be understood separately from theatrological concepts, such as dramaturgy, scenography, etc. "The suggested process of analysis tries to be a bridge between science and art. It is an attempt to study an artistic phenomenon in a scientific way" (Žavbi Milojević, 2013b, p. 220).

Here is an example of an analysed scene or a short segment of speech in this scene.

1. analysed scene: Teachers after the elections

General findings regarding stage speech in the first analyzed scene:

It is typical for this scene that the characters perform only parts of the dramatic text and not in the same order as in the drama, often lines are performed by different characters than in the dramatic text. Speech, mimic and gesture suggest a macabre mood, however, that quickly changes because teachers

6 Ivan Cankar: The Serfs. Director: Sebastijan Horvat. Author of adaptation and dramaturgy: Milan Marković Matis. Set designer: Jürgen Kirner. Costume designer: Belinda Radulović. Composer: Drago Ivanuša. Language consultant: Tatjana Stanič. Assistant director: Žiga Divjak. Cast: Radko Polič - Jerman, Romeo Grebenšek - Young Jerman, Jure Kopušar - Vicar, Nikla Patruška Panizon - Lojzka, Iztok Drabik Jug - Senior Teacher, Primož Forte - Kalander, Maja Blagovič - Mother, Matija Rupel - Komar, Patrizia Jurinčič - Minka, Tina Gunzek Anka, Luka Cimprič - Pisek. 
decide not to mourn but to change their beliefs. The prosodic element that is most intensely used is pause which is often very long. The speech does not show the intense emotions of the speakers but mostly their calmness, resignation, etc.

Audio analysis of stage speech on the example of one utterance:

Senior Teacher (Mayor in the drama): The nation is healthy, honest.

Nonverbal communication: Senior teacher has his hands on his hips, he looks at Komar and is nodding slightly.

Intonation and pause: The nation $[\downarrow] \|$ is healthy, $[\downarrow] \|$ honest. $\left.\downarrow\right|^{7}$

Words spoken louder or stressed: The nation is healthy, honest.

An example of Praat phonetic computer programme analysis:

hlapci_servi_2015_4

$2 . \overline{3} 714 \overline{6259}$

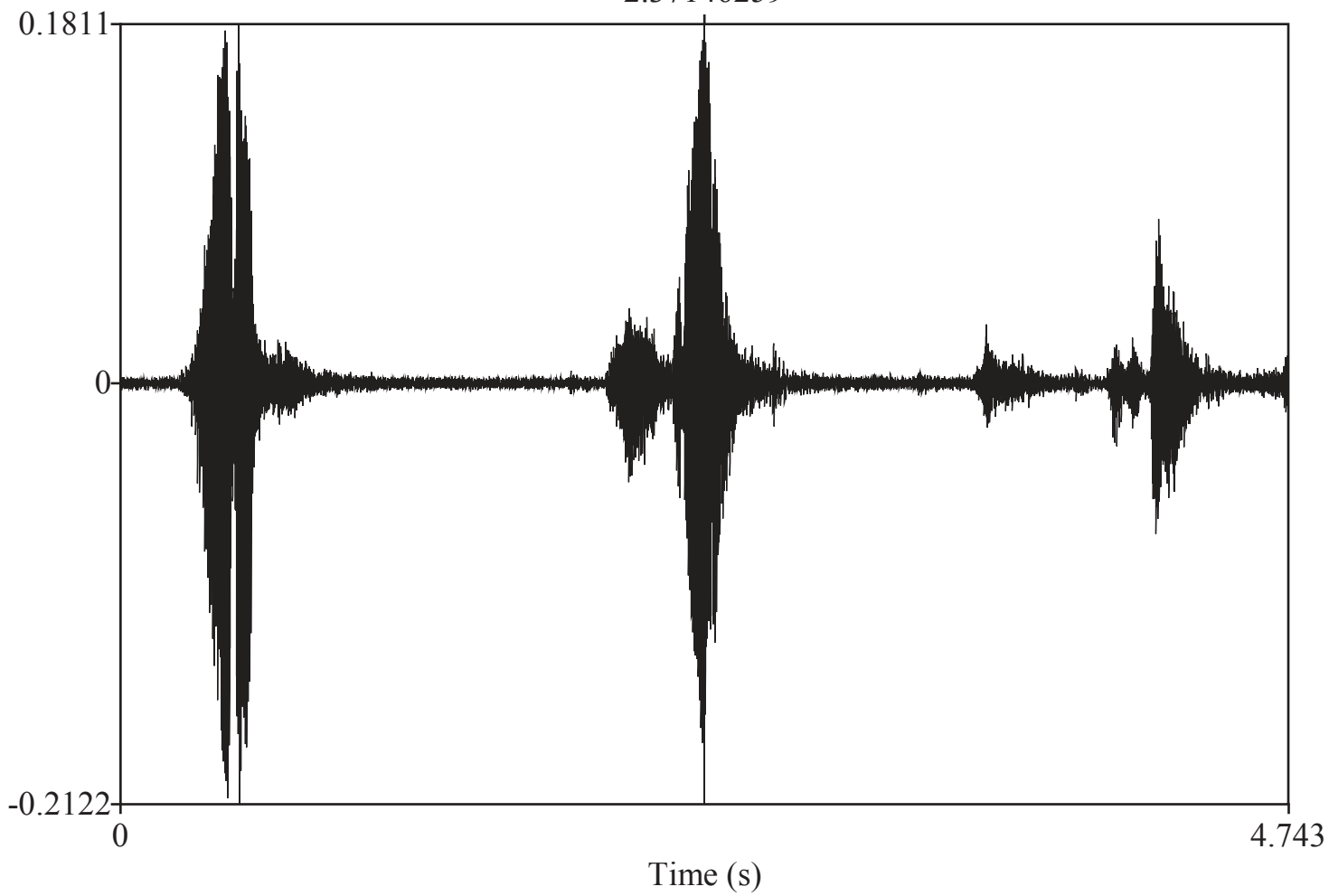

Fig. 1. Oscillogram

Source: author

The oscillogram shows that the utterance was broken up by two longer pauses (both 1,1 second). The speech is slow - the speaker produced 6 syllables in 4,4 seconds, which is 1,4 syllable per second. ${ }^{8}$ The speech is quiet - the average loudness was measured at $61,6 \mathrm{~dB}$ in the first part of the utterance (The nation is healthy,) and $53,9 \mathrm{~dB}$ in the second part (honest.). I divided the utterance into two parts because there was also a sound (sneezing in the audience) recorded in the pause which should, however, not be included in

7 The symbols I use to mark intonation and pause are taken from the classification by Katarina Podbevšek: $[\downarrow]$ falling intonation, $\downarrow$ falling intonation at the end of a sentence (Podbevšek, 2007, p. 111), || medium length pause, | short pause (Podbevšek, 2006, p. 109).

8 Medium speed is 4-7 syllables produced in a second (Vuletić, 2007, p. 72; Škarić, 1991, p. 298). 
the analysis. The second part of the utterance was spoken more quietly and there was a longer pause prior to it which could suggest doubt whether the nation really is honest. In this way we can interpret the prosodic elements used in the utterance. The actor's pitch range is small in both parts of the utterance: $97,2 \mathrm{~Hz}(86,7-183,9 \mathrm{~Hz})$ in the first part and $81,9 \mathrm{~Hz}(92,5-174,4 \mathrm{~Hz})^{9}$ in the second part. Praat computer programme confirmed that the intonation is falling. The intensity of all elements was low. The prosodic elements are typical for expressing sadness ${ }^{10}$.

The prosodic elements (pause, intonation, tempo and loudness) and nonverbal communication used in the first analysed scene reveal to us if the utterances are true - we can conclude this when the prosodic elements and nonverbal communication do not correspond with the content of the speech. The result of the audio analysis was also confirmed by the Praat computer programme analysis. Interpretation of results of phonetic analysis (which is shown in the example) has to be interdisciplinary - phonetic analysis itself only describes stage speech but gives no information about effects of certain use of prosodic elements. The researcher has to analyse how the specific stage speech is included in specific staging which can be concluded only by combining phonetics, theatre studies, sociolinguistics etc. For example the researcher tries to establish how slow stage speech is intergrated in staging The Serfs, how it supports the director's concept, dramaturgy, scenography, etc.

From the example described above it is evident that modern research of stage speech - concept that combines two steps: audio analysis and analysis with phonetic computer programme - is interdisciplinary and tries to connect different fields and does not stay strictly within the boundaries of linguistics (phonetics); it tries to connect science and art; it tries to understand stage speech as part of the staging as a whole - where speech is just one of the elements that comprise an individual staging; it also tries to be as objective as possible.

\section{TEACHING STAGE SPEECH}

Teaching stage speech has been part of the curriculum for students of Stage Acting at the Academy of Drama Arts since the very beginning in 1946. It all started to change when »the Academy took over the pedagogic model of the Zagreb school of phonetics founded by Petar Guberina and applied to artistic speech by Ivo Škarić« (Faganel, 2006, p. 15, 16). The s.c. verbotonal method was finally established as the main method by Ana Vuga - Vogel. Tomaž Gubenšek expanded this method with the knowledge from Cicely

9 The data show that the pitch range is $100-200 \mathrm{~Hz}$ for statements and 130-300 for exclamations (Vuletić, 2007, p. 78).

10 Sadness and fear have very similar pitch contours: the register is low with a very small pitch range - between 88 and $240 \mathrm{~Hz}$ for fear and between 83 and $152 \mathrm{~Hz}$ for sadness. When the utterance reveals fear it is also faster. The intensity is low for both emotions (Vuletić, 2007, p. 94-97). 
Berry's British approach that takes the understanding of the complete text and its technical components as the basis when dealing with speech « (Faganel, 2006, p. 16).

The curriculum of Stage Acting students is a mixture of theoretical knowledge and practical skills. The Chair of Speech strives to make the connection between theory and practice regarding speech and voice in different subjects (lectures, seminars and practical classes). At the same time they want to make sure that all knowledge gained in theoretical classes is usable in practice, therefore, relevant to the students' future profession. Subjects covering the area of phonetics, text phonetics, stylistics and rhetorics, include a wide range of theoretical knowledge. They are, however, always planned in such a way that students focus on how they can use their knowledge in the acting profession. Especially in practical lessons, an obligatory part of every subject, students get the opportunity to apply theoretical knowledge to concrete examples of stagings - e.g. with video - more often this is done through production prepared by students as part of their Stage Acting class. If for example students are preparing the production of Antigone by Sofokles in their Stage Acting class, they are dealing with dramatic verse in Language and Speech III - they can discuss verse systems and how to perform them. In this way students can test their theoretical knowledge on concrete examples. Besides the above mentioned theoretical areas covered by Katarina Podbevšek and Nina Žavbi Milojević, Tomaž Gubenšek and Alida Bevk teach speech techniques. They deal mostly with articulatory preparation for the act of speaking, teach students about the theory and practice of the Slovene vocal system and teach students how to correctly articulate different sounds by using breathing techniques and the use of breath when speaking. Vladimir Jurc teaches Stage Speech where students test their theoretical knowledge by practising with concrete texts. The fundamental subject throughout the study is Stage Acting where two teachers work together at all times. One is an educated professional actor who primarily teaches students of Stage Acting, the other is a teacher who is also a professional director. The approach to work is comprehensive - both teachers and students of Stage Acting and students of Theatre Directing take part in a complex process which also involves students of Dramaturgy, Costume and Set Design. As mentors from the Chair of Speech we enter the creative process at some stages of the s.c. production (a performance prepared in a certain semester by students mentored by their teachers) when we deal with the playscript - »scoring the written text « (Podbevšek, 1989/1990, p. 27) and the speech of actors - »scoring the spoken text « (Podbevšek, 1989/1990, p. 27) and this occurs during practical classes. As mentors of speech we teach students different skills: proper articulation and pronunciation, how they interpret the spoken text on the basis of the intended effect of the author, and we also encourage our students to use their speech and voice to individually create their characters. And this is done mostly by prosodic elements of speech. 


\section{MODERN TEACHING AND RESEARCHING OF STAGE SPEECH - CONNECTIONS}

Modern research of stage speech is more and more interdisciplinary, it also strives to be as objective as possible. Because researchers of speech are mostly also teachers of speech I was interested in how the way in which we conduct research - mostly the methods and theoretical basis - influences the teaching practice. My conclusions are based on my personal teaching practice at UL AGRFT, where I work as an assistant for the field of speech.

1. My first observation refers to the various technological possibilities for

researching stage speech and their influence on teaching speech

The possibility to listen to the same recording or to see the same video several times is key to the scientific research of stage speech. Therefore, it was essential that the technology allowing such research was developed as well as the fact that different stagings in professional theatres were recorded only then we could start researching stage speech in depth. A new milestone in speech research was the development and availability of computer technology that an individual can use on his personal computer to phonetically analyse speech (e.g. Praat phonetic programme).

The above mentioned technology significally changed reasearching and teaching stage speech. When we discuss nonverbal communication and prosodic elements in theory (Language and Speech II for second year students of Stage Acting), we always show the students a few videos of different stage speeches from concrete stagings. Namely, students of Stage Acting need the constant connection between theory and practice, they need to constantly apply their theoretical knowledge to their future professional activity. They need to see how to use theoretical knowledge, which they acquiered in lectures, in practice. Students then test their knowledge by performing different texts, mostly the text they are at the same time preparing for Stage Acting. Another way in which technology influences the methods of teaching is the use of phonetic computer programmes for researching stage speech. I show my students in Language and Speech II how they can objectively measure the realisation of speech of a concrete text including a text performed by the students themselves. The latter is always fascinating for the students. We watch a video of their last production and analyse their voices - I show them their register, tempo, and the moods that they set with their voices. The students are surprised when they see how they subconsciously use nonverbal and prosodic elements in a way that is effective - e.g. how they use a slow, quiet speech and a low pitch to express the emotion of sadness, and to express happiness they use loud, fast speech and a high pitch. Students realize that the theoretical knowledge they acquiered is not only theory but something they can actually use in their acting profession. They also learn about the parameters of their voices and speech and become more aware of them. We constantly intertwine theory and practice as well as science and art - the students of Stage Acting also understand that stage speech can be a subject of scientific 
research and that science can help them understand their speech and have a positive influence on it.

2. The second observation refers to the interdisciplinary approach to researching stage speech and the influence it has on teaching speech.

As has been shown in this article researching stage speech connects linguistics or phonetics with philosophy, psychology, sociolinguistics, theatre studies, etc.

An interdisciplinary approach has always been used at the Academy, especially in the subject of Stage Acting, where students of different study programmes and their mentors work together - students are involved in the creative process the result of which is a staging. They are aware of the fact that a staging comprises of different elements that function together and communicate the director's vision of the staging to the audience. The Chair of Speech also uses the interdisciplinary approach for each individual subject. Language and Speech II for example connects the knowledge on text phonetics with dramatic theory and language technologies, including sociolinguistics, etc. Stage speech is always presented as one of the elements of staging and the focus is always on its role in the staging. And this direct link to practical use makes the subject of teaching interesting to the students of Stage Acting.

Both observations I have described above show how closely connected teaching and researching stage speech are and that the methods and findings of research constantly influence the methods of teaching stage speech at the Academy. The research technology and an interdisciplinary approach are both used in the process of teaching as well.

\section{CONCLUSION}

In conclusion I return to my original statement that modern methods of researching stage speech influence the teaching of this artistic phenomenon. As I have shown in the article, modern research methods are interdisciplinary and because of the development and availability of technology (phonetic computer programme), which allows measurable results, they are also increasingly objective. Researching the artistic phenomenon of stage speech tries to reduce the gap between art and science or rather to create a connection between art and science. Teaching stage speech has tried to balance between theory and practice throughout the history of the Academy of Theatre, Radio, Film and Television, and by using modern teaching methods also connected the science of speech and art. An interdisciplinary approach is used in teaching as well, theoretical concepts are substantiated by videos, data and graphs acquiered with the use of phonetic computer programmes - the use of technology.

The methods of researching stage speech and the theoretical concepts developed during research also influence the teaching practice. And if we 
leave some room for imagination we could also say that researching stage speech influences the art itself or the performance on stage of future generations of actors.

\section{REFERENCES}

[1] Boersma, P., Weenink, D. (2016). Praat: Doing Phonetics by Computer. Retrieved from http:// www.fon.hum.uva.nl/praat/.

[2] Cankar I., Hlapci. Videoposnetek uprizoritve v režiji Sebastijana Horvata [The Serfs: A Video of the Staging, directed by Sebastijan Horvat]. Slovensko stalno gledališče Trst. Sezona 2014/2015. Premiere 20.5.2015.

[3] Faganel, J. (2006). Razvoj pedagoških nazorov o igralčevem govoru [Developing Pedagogical Views on Actor's Speech]. In: K. Podbevšek, T. Gubenšek (Eds.), Kolokvij o umetniškem govoru 2 [A Colloquium on Artistic Speech2]. (pp. 13-17). Ljubljana: Akademija za gledališče, radio, film in televizijo, Katedra za govor.

[4] Humar, M., Sušec Michieli, B., Podbevšek, K., Lokar, S. (2007). Gledališki terminološki slovar [A Glossary of Theatre Terms]. Ljubljana: Založba ZRC.

[5] Podbevšek, K. (1989/1990). Na novo odkriti govor (učna izkušnja na AGRTV) [Newly Discovered Speech (a Teaching Experience at the Academy of Theatre, Radio, Film and television)]. Jezik in slovstuo [Language and Literature], 35 (1-2), 27-31.

[6] Podbevšek, K. (1996). Poučevanje jezika in govora na Akademiji [Teaching Language and Speech at the Academy]. In: A. Inkret (Ed.),Akademija za gledalǐ̌če, radio, film in televizijo: 50 let: 1946-1996 [Academy of Theatre, Radio, Film and Television: 50 years: 1946-1996]. Ljubljana: Akademija za gledališče, radio, film in televizijo.

[7] Podbevšek, K. (2006a). Uvod [An Introduction]. In: K. Podbevšek, T. Gubenšek (Eds.), Kolokvij o umetniškem govoru 2 [A Colloquium on Artistic Speech]. (pp. 7-9). Ljubljana: Akademija za gledališče, radio, film in televizijo, Katedra za govor.

[8] Podbevšek, K. (2006b). Govorna interpretacija literarnih besedil v pedagoški in umetniški praksi [Speech Interpretation of Literary Texts in School and Artistic Practice]. Ljubljana: Slavistično društvo Slovenije.

[9] Podbevšek, K. (2010). Spreminjanje odrske govorne estetike v slovenskem gledališču 20. stoletja [Changes in the Stage Speech Aesthetics in Slovenia during the 20th Century]. In: B. Sušec Michieli, B. Lukan, M. Šorli (Eds.), Dinamika sprememb v slovenskem gledališču 20. stoletja [Dynamics of Changes in the Slovene Theatre in the 20th Century]. (pp. 195-238). Ljubljana: Akademija za gledališče, radio, fim in televizijo, Maska.

[10] Podbevšek, K. (2012). Odrska govorna estetika v slovenskem dramskem gledališču (dva primera) [Stage Speech Aesthetics in the Slovene Drama Theatre (two examples)]. In: M. Pezdirc Bartol (Ed.), Slovenska dramatika [The Slovene Drama]. (pp. 249-256). Ljubljana: Znanstvena založba Filozofske fakultete.

[11] Podbevšek, K. (2013). Govor - skupni raziskovalni predmet znanosti in umetnosti [Speech a Common Subject of Research for Science and Art]. In: K. Podbevšek, N. Žavbi Milojević (Eds.), Govor med znanostjo in umetnostjo [Speech Between Science and Art]. (pp. 9-11). Maribor: Aristej.

[12] Škarić, I. (1991).Fonetikahrvatskogaknjiževnogjezika [Phonetics of the Croatian standard language]. In: S. Pavešić, I. Škarić, S. Težak, Povijesnipregled, glasoviioblicihrvatskogknjiževnogjezika [A Historical Overview, Sounds and Forms of the Croatian Standard Language]. (pp. 63-376). Zagreb: HAZU globus.

[13] Tivadar, H. (2004). Priprava, izvedba in pomen perceptivnih testov za fonetično-fonološke raziskave (na primeru analize fonoloških parov) [Design, implementation and significance of perception tests for phonetics and phonological research (the case of phonological pairs)]. Jezik in slovstuo, 49 (2), 17-36.

[14] Verovnik, I. (2001). Uporaba računalnika pri obravnavi zvočnih pojavov. Modeli poučevanja in učenja. Fizika [Use of Computer for discussing sound phenomena: Models of teaching and studying]. Ljubljana: Zavod RS za šolstvo. 
[15] Varošanec-Škarić, G. (2005). Timbar [Timbre]. Zagreb: FF press.

[16] Vrban Zrinski, K. (2013). Prozodijski čimbenici suvremenoga scenskoga člumačkoga govora, doktorski rad [Prosodic Features in Contemporary Actors' Speech, Doctoral Thesis]. Zagreb: Sveučilište u Zagrebu, Filozofski fakultet.

[17] Vuletić, B. (2007). Lingvistika govora [Linguistics of Speech]. Zagreb: FF Press.

[18] Žavbi Milojević, N. (2013a). Analiza odrskega govora: primer Bergerjeve uprizoritve Hlapcev (Komentirana izdaja) [An Analysis of Stage Speech: The Example of Berger's Staging of Serfs (An Annotated Edition)]. Slavistična revija, 61 (4), 651-664.

[19] Žavbi Milojević, N. (2013b). Uporaba računalniškega programa Praat pri analizi odrskega govora [Using the Praat Computer Programme for the Analysis of Stage Speech]. In: K. Podbevšek, N. Žavbi Milojević (eds.), Govor med znanostjo in umetnostjo [Speech Between Science and Art]. (pp. 217-224). Maribor: Aristej. 